\title{
EXPERIMENTAL INVESTIGATION ON THE THRESHOLD CHLORIDE CONCENTRATION FOR CORROSION INITIATION IN REINFORCED CONCRETE STRUCTURES
}

\author{
Byung Hwan Oh \\ Professor, Dept. of Civil Engineering, \\ Seoul National University, Korea \\ Phone: (+822)880-7350, \\ Fax: $(+822) 887-0349$ \\ E-mail: bhohcon@snu.ac.kr
}

\author{
Seung Yup Jang \\ Senior researcher, Korea Railroad Research, \\ Korea \\ Phone: $(+822) 880-7350$, \\ Fax: $(+822) 887-0349$ \\ E-mail: jsy7291@msn.com
}

\begin{abstract}
The corrosion of steel reinforcements in concrete is of great importance in the view of safety and durability of reinforced concrete structures. This study is focused on the corrosion behavior of steel bars induced by internal chlorides in concrete. The main objective of this study is to determine the threshold chloride concentration causing depassivation and active corrosion of steel reinforcement in concrete. To examine the threshold concentration of chloride ion, the half-cell potential, the chemical composition of extracted pore solutions of concrete and the extent of corroded area of the specimens were measured. Major test variables include the added amount of chlorides in concrete, type of binder, and water-to-binder ratios. From the present comprehensive test results, the factors influencing threshold chloride concentration are investigated, and the rational ranges of threshold chloride concentration causing active corrosion of steels are proposed. The present study provides the realistic chloride limit for corrosion initiation of reinforced concrete structures, which can be used efficiently in the future technical specification.
\end{abstract}

Keywords: Chloride, Threshold, Corrosion initiation, Chloride limit, Reinforced concrete structures.

\section{INTRODUCTION}

The corrosion of steel reinforcement in concrete is of great concern in recent years as the durability is becoming more important in concrete structures. Especially, chloride-induced corrosion of reinforcing steel is increasingly important in many countries due to increased use of sea sand and heavy construction of marine structures. Although many investigators (Kropp, 1995; Schiessl, 1997; Hausmann, 1967; Gauda, 1970; Stratfull, 1973; Khan, 1991; Lorentz, 1995; Page, 1991; Lambert, 1991; Tayyib, 1988) have studied the mechanism of chloride-induced corrosion, the chloride ion concentration that causes the initiation of steel corrosion in concrete a most important parameter in determining the durability life and/or service life of concrete structures - is still ambiguous and needs further study. This threshold concentration for corrosion initiation is known to be affected by a number of factors including cement content, type of binder, chloride binding, concentration of hydroxyl ions, etc (Krop, 1995). This study is focused on the corrosion of steel bars induced by internal chlorides in concrete at early ages. The main objective of this study is to determine the threshold chloride ion concentration causing depassivation and onset of active corrosion of steel reinforcement in concrete. To this end, a comprehensive experimental program has been set up, and a large number of specimens have been tested. The major test variables include chloride concentrations, type of cement and mineral admixtures, and water-to-binder ratios. To examine the threshold chloride concentration, half-cell potentials and chemical composition of extracted pore solutions were observed according to the added amount of chlorides, type of binder and water-to-binder ratios. From the 
present test results, the factors influencing threshold chloride concentration are investigated, and the rational ranges of threshold chloride concentration causing active corrosion of steel are proposed. In particular, the effects of the water-to-binder ratios, and the type and amount of binder on the threshold chloride concentration have not been well clarified yet. The effects of various parameters such as $\mathrm{C}_{3} \mathrm{~A}$ content, alkali content, and $\left[\mathrm{Cl}^{-}\right] /\left[\mathrm{OH}^{-}\right] \mathrm{ratios}^{-}$ on the chloride binding also need to be identified. Therefore, this study has great importance to establish the threshold total and free chloride ion concentration for the initiation of corrosion steel bars in concrete structures.

\section{CORROSION TESTS OF STEEL BARS IN CONCRETE}

\subsection{Materials and specimen preparation}

The test variables are summarized in Table 1. The major test variables include the types of cement, water-to-binder ratios, use of mineral admixtures and admixed chloride contents. The chlorides were admixed into concrete specimens as sodium chloride, of which concentrations vary from zero to two percent by weight of binder (i.e. $0.0,0.2,0.4,0.6,0.8,1.2,1.6$ and $2.0 \%$ ) for all the test series as shown in table 1 , respectively. Table 2 shows the chemical composition of various binders and Table 3 gives the chemical compounds of the cements. Table 4 summarizes the mixture proportions for various water-to-binder ratios. The prismatic mortar specimens $(100 \times 100 \times 200 \mathrm{~mm})$ with a $13 \mathrm{~mm}$ steel bar embedded centrally, as shown in Fig. 1, were cast in steel molds. The specimens were demoulded after $24 \mathrm{hr}$ and cured in $20 \pm 2^{\circ} \mathrm{C}$ temperature and $95 \pm 5 \%$ relative humidity.

Table 1. Summary of major test variable

\begin{tabular}{c|c|c|c|c}
\hline Test series & Water/binder ratio & Types of cement & $\begin{array}{c}\text { Mineral admixtures } \\
(\%, \text { by binder weight })\end{array}$ & $\begin{array}{c}\text { Total chloride } \\
\text { addition }\end{array}$ \\
\hline LI & 0.55 & Type I & - & $0,0.2,0.4,0.6$, \\
NI & 0.45 & Type I & - & $0.8,1.2,1.6,2.0$ \\
HI & 0.35 & Type I & - & $(\%$ by weight of \\
NV & 0.45 & Type V & Finders $)$ \\
NIFA15 & 0.45 & Type I & Fly ash $15 \%$ & \\
NIFA30 & 0.45 & Type I & Slag 30\% & \\
NIS30 & 0.45 & Type I & & \\
\hline
\end{tabular}

Table 2. Chemical composition of cementitious materials

\begin{tabular}{|c|c|c|c|c|c|c|c|c|c|}
\hline \multirow{2}{*}{ Binders } & \multicolumn{9}{|c|}{ Oxide composition percent by weight } \\
\hline & $\mathrm{CaO}$ & $\mathrm{SiO}_{2}$ & $\mathrm{Al}_{2} \mathrm{O}_{3}$ & $\mathrm{Fe}_{2} \mathrm{O}_{3}$ & $\mathrm{MgO}$ & $\mathrm{K}_{2} \mathrm{O}$ & $\mathrm{Na}_{2} \mathrm{O}$ & $\mathrm{SO}_{3}$ & LOI \\
\hline Type I & 61.20 & 22.00 & 6.20 & 3.20 & 2.80 & 1.10 & 0.10 & 2.00 & 1.40 \\
\hline Type V & 62.03 & 22.11 & 4.20 & 4.27 & 2.87 & 0.72 & 0.09 & 2.03 & 1.70 \\
\hline Slag & 43.34 & 33.86 & 14.67 & 0.32 & 5.95 & 0.61 & 0.19 & 0.12 & 0.67 \\
\hline Fly ash & 3.89 & 59.74 & 23.60 & 6.07 & 0.95 & 0.96 & 0.49 & 0.40 & 3.90 \\
\hline
\end{tabular}

Table 3. Chemical compound of cement

\begin{tabular}{c|c|c|c|c|c}
\hline \multirow{2}{*}{ Binders } & \multicolumn{4}{|c}{ Compound composition percent by weight } \\
\cline { 2 - 6 } & $\mathrm{C}_{3} \mathrm{~S}$ & $\mathrm{C}_{2} \mathrm{~S}$ & $\mathrm{C}_{3} \mathrm{~A}$ & $\mathrm{C}_{4} \mathrm{AF}$ & Alkali \\
\hline Type I & 35.7 & 36.2 & 11.0 & 9.7 & 1.2 \\
Type V & 50.1 & 25.6 & 3.9 & 13.0 & 0.8 \\
\hline
\end{tabular}

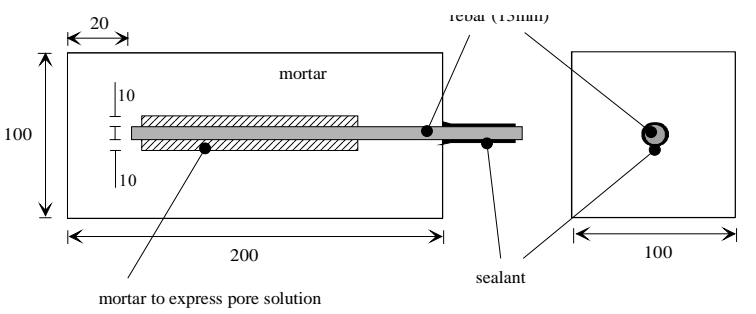

Fig. 1 Schematic diagram of test specimens

\subsection{Measurement of half-cell potential and pore solution extraction}

Half-cell potentials were measured every 3 days for all specimens using a copper-copper sulfate reference electrode (CSE), in accordance with ASTM C-876 (1990). After 30 days, the pore solution was extracted from the mortar around the steel bar and the $\mathrm{Cl}^{-}$concentration and $\mathrm{OH}^{-}$concentration were measured. Pore solution extraction of the specimens was performed by the pore solution expression method, which can be found elsewhere (Barneyback, 1981 and Arya, 1990). The free chloride concentration and $\mathrm{OH}^{-}$concentration were measured by ion chromatography and direct titration using phenolphthalein indicator from the extracted pore solution.

\subsection{Measurement of corroded areas}

The steel bars were extracted from the specimens, and then the corroded area of each bar was measured by 
drawing the steel surface on the transparent film wrapping it with equally-spaced grids and counting the numbers of nodes in the grids that belong to the corroded zone (see Fig. 2). Then the extent of corroded area $A_{\text {corr }}$ is calculated from

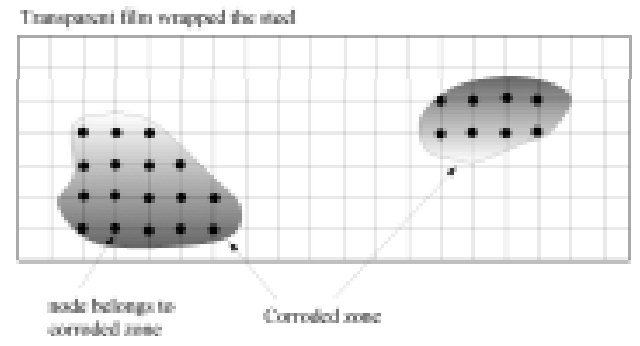

$$
A_{\text {corr }}=\frac{\text { numbers of nodes that belong to corroded zone }}{\text { total numbers of nodes }}
$$

Fig. 2 Measurement of corroded area

\section{RESULTS AND DISCUSSION}

\subsection{Half-cell potential values}

Fig. 3 shows the half-cell potential measurements for the ordinary cement concrete mixed with $0.0,0.2,0.4,0.6$, $0.8,1.2,1.6,2.0$ percent sodium chloride, respectively. The half-cell potential values for various cases have a tendency to increase in early ages and then approaches to certain uniform values.

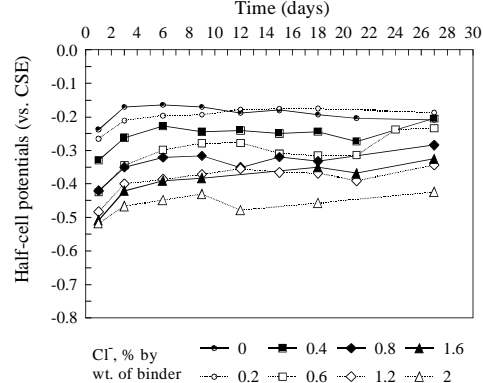

Fig. 3. Variation of half-cell potential with age $(O P C$, $w / c=0.45)$

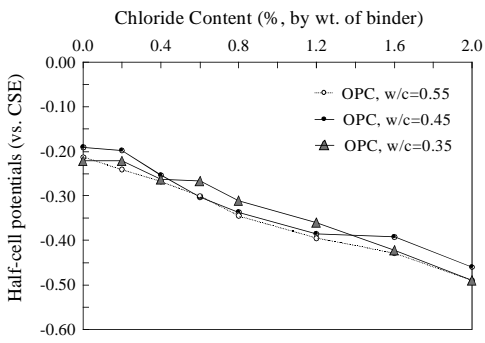

Fig. 4 Variation of half-cell potential with chloride content (effect of water/binder ratio)

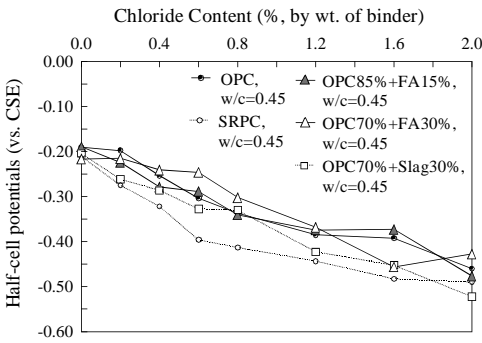

Fig. 5 Variation of half-cell potential with chloride content (effect of types of binders)

Fig. 4 shows the variation of half-cell potentials according to chloride contents for various water-to-binder ratios. It is seen that the half-cell potential values decrease linearly with the increase of chloride content and that the values are similar for different water-to-binder ratios. Fig. 5 depicts the variation of half-cell potentials with chloride contents for various types of binder. This figure indicates that the mixture with Type V cement (SRPC) exhibits the lowest values of half-cell potentials and the other mixtures show similar potential values. Fig. 5 also indicates that the half-cell potentials decrease as chloride contents increase.

In general, the potential value of $-0.35 \mathrm{~V}$ (vs. CSE) is taken as the threshold potential for corrosion initiation according to ASTM. Fig. 4 and Fig. 5 may be allowed to determine the realistic amount of chloride contents corresponding to the half-cell potential value of $-0.35 \mathrm{~V}$.

\subsection{Extent of corroded areas}

Fig. 6 shows the corroded area of steel bar according to chloride contents. It can be seen that the corrosion area decreases with a decrease of water-to-binder ratios and also decreases with the use of mineral admixtures. The general tendency is that the corrosion area increases with an increase of the chloride content as shown in Fig. 6 . It can also be seen that the steel bars embedded in type V sulfate-resisting cement (SRPC) show a relatively larger corrosion area at the same chloride contents. Fig. 7 shows the relation between the extent of corroded area and the half-cell potential values. It can be clearly seen from Fig. 7 that the corrosion of steel initiates at a value of about $0.25 \mathrm{~V}$. The extent of corroded area after 30 days is about 3 percent at $-0.35 \mathrm{~V}$.

\subsection{Relation between total chloride and free chloride contents}

The relation between total chloride addition and free chloride content obtained by pore solution expression is shown in Fig. 8. As shown in Fig. 8, the free chloride content increases gradually, as the added total chloride 


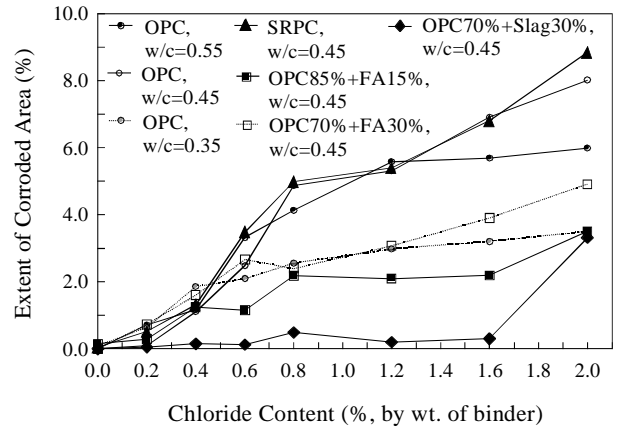

Fig. 6 Extent of corroded area versus chloride content

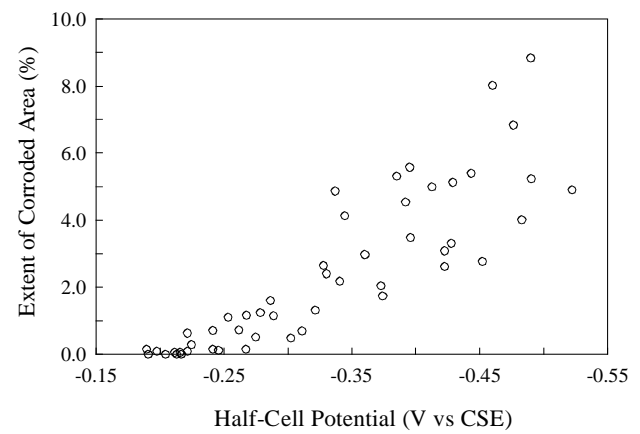

Fig. 7 Extent of corroded area versus half-cell potential

content increases. It is seen that the free chloride content is highest for the case of Type V cement mixture (SRPC) at the same total chloride addition. This fact is particularly pronounced in Fig. 10 where the two cement types are compared at the same water-to-binder ratio of 0.45 . This indicates that the chloride binding capacity of Type $\mathrm{V}$ sulfate-resisting cement (SRPC) is lower than that of Type I ordinary cement (OPC). Fig. 9 shows quantitatively the relation between the total chloride content and the free chloride content for the mixtures with different water-to-binder ratios. Fig. 9 indicates that the free chloride content increases with the increase of water-to-binder ratios. Fig. 10 shows that type $\mathrm{V}$ cement exhibits more free chloride content at the same amount of total chloride addition than type $\mathrm{I}$ cement. This is due to the different binding effects according to $\mathrm{C}_{3} \mathrm{~A}$ amount in cement. Fig. 11 shows the effect of mineral admixtures on the chloride binding. This figure indicates that the effect of mineral admixtures on the chloride binding is not large at early ages. Fig. 12 also shows the effects of various parameters on the chloride binding, including $\mathrm{C}_{3} \mathrm{~A}$ content, alkali content, $\mathrm{OH}^{-}$concentration. It can be seen that an increase of the $\mathrm{C}_{3} \mathrm{~A}$ content of the cement decreases the free chloride content, which means increased chloride binding capacity. The alkali content and $\mathrm{OH}^{-}$concentration also affect the chloride binding. The free chloride contents decrease with the increase of alkali content and $\mathrm{OH}^{-}$concentration.

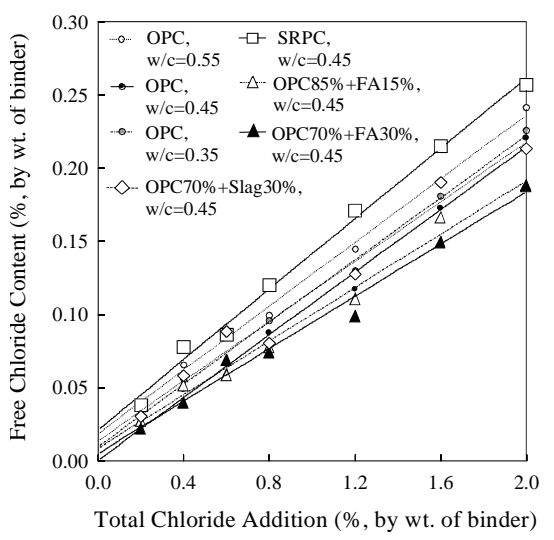

Fig. 8 Relation between total chloride content

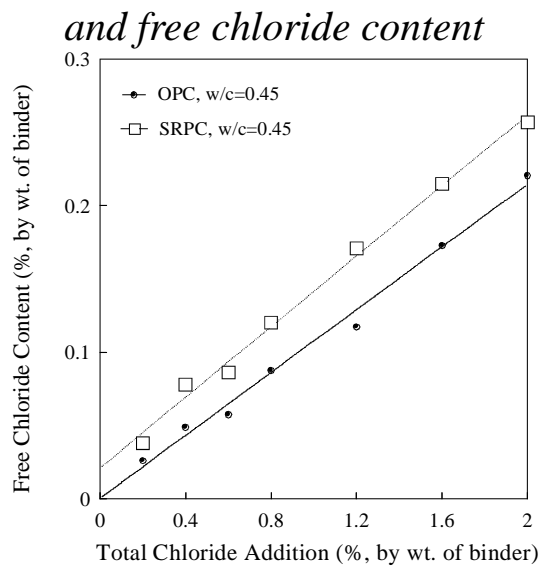

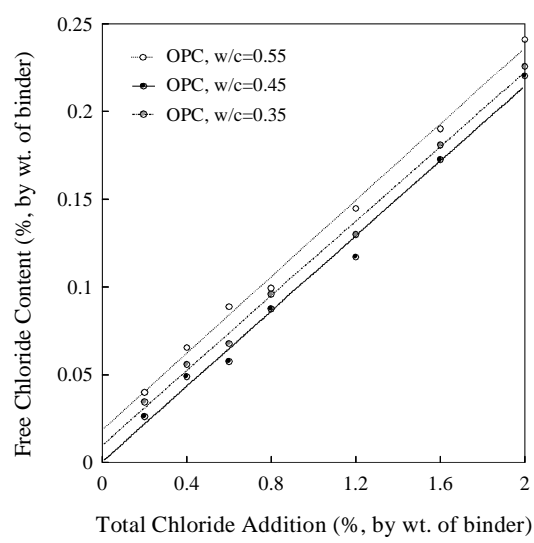

Fig. 9 Relation between total and free chloride

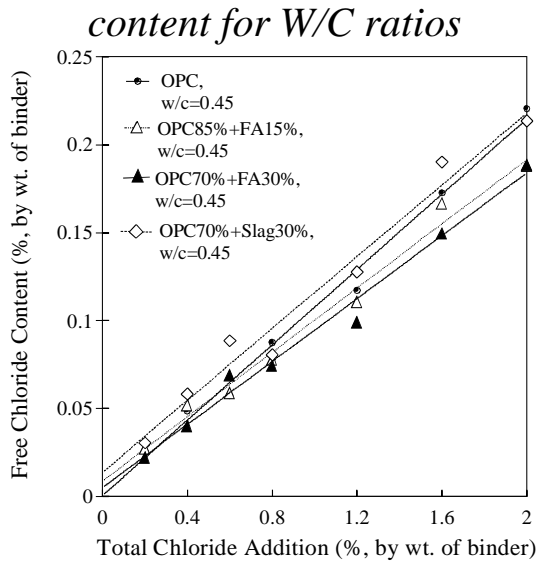

Copyright $\odot 2005$ by SMiRT18 
Fig. 10 Relation between total and free chloride content for cement type

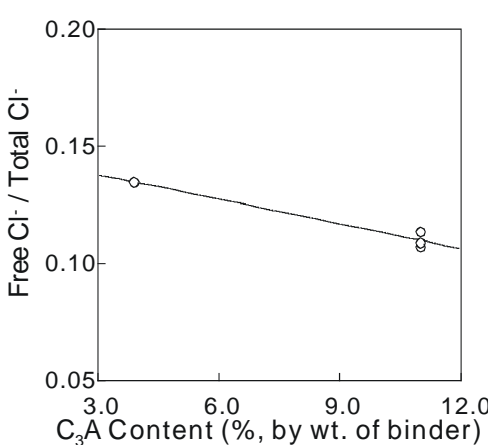

(a) $\mathrm{C}_{3} \mathrm{~A}$ content

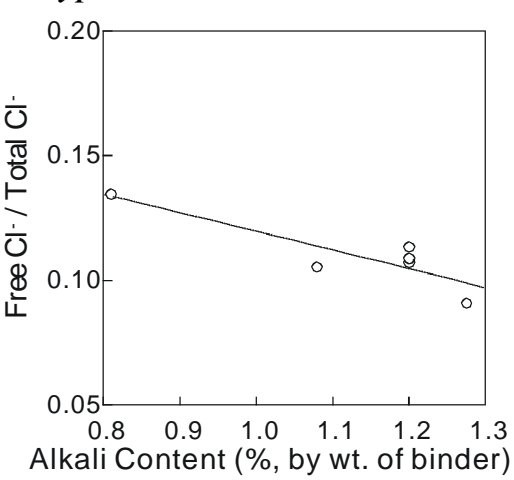

(b) alkali content
Fig. 11 Relation between total and free chloride content for admixture

Fig. 12 Variation of chloride binding

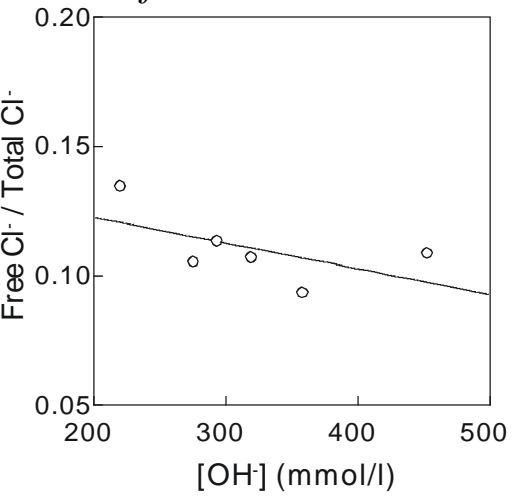

(c) $\mathrm{OH}$ - concentration in pore solution

\section{osion \\ 3.4 Threshold values for corrosion}

The total chloride addition, the free chloride content and $\left[\mathrm{Cl}^{-}\right] /\left[\mathrm{OH}^{-}\right]$ratios have been plotted according to the half-cell potential in Fig. 13 (OPC, w/c=0.45). As shown in Fig. 13, the total chloride addition, the free chloride content and $\left[\mathrm{Cl}^{-}\right] /\left[\mathrm{OH}^{-}\right]$ratios are linear relations of the half-cell potential. If the potential $\mathrm{E}=-300 \mathrm{mV}$ vs. CSE at which the extent of corroded area increases significantly from the relation between the extent of corroded area and half-cell potential, as shown in Fig. 7, is taken as the potential for the initiation of corrosion, the threshold chloride concentration corresponding to this potential value can be found from Fig.13. The threshold values for total chloride addition, free chloride content and $\left[\mathrm{Cl}^{-}\right] /\left[\mathrm{OH}^{-}\right]$were determined for each of the various mixtures, and the results are given in Table 5 .

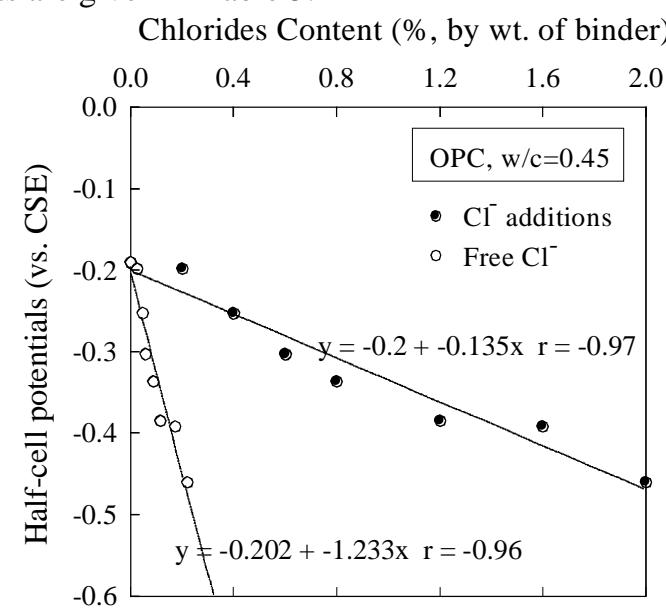

(a)

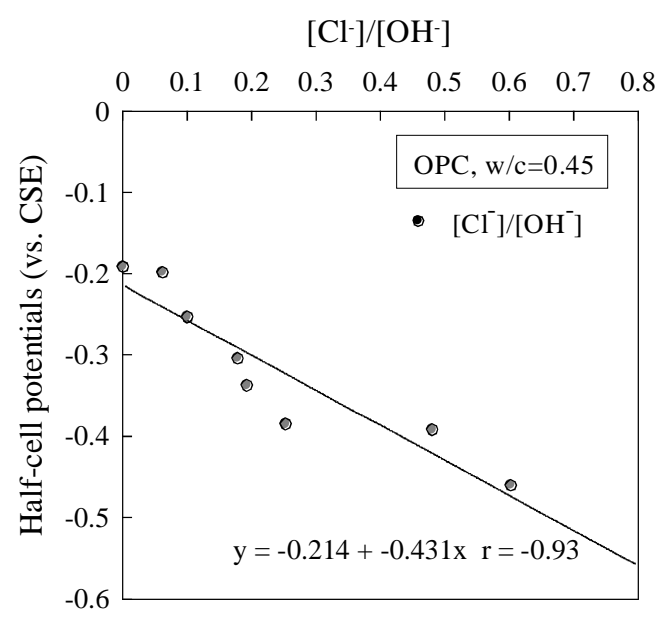

(b)

Fig. 13 Relation between half-cell potential and chloride content, and deduction of chloride thresholds

Table 5 Threshold chloride values obtained from the present study

\begin{tabular}{c|c|c|c}
\hline \multirow{2}{*}{ Types of mixture } & \multicolumn{3}{|c}{ Chloride threshold values } \\
\cline { 2 - 4 } & $\begin{array}{c}\text { Total Cl } \\
\text { (\%, by binder weight })\end{array}$ & $\begin{array}{c}\text { Free } \mathrm{Cl}^{-} \\
(\%, \text { by binder weight })\end{array}$ & 0.12 \\
\hline LI & 0.78 & 0.11 & 0.16 \\
NI & 0.93 & 0.12 & 0.26 \\
HI & 0.89 & 0.10 & 0.19 \\
NV & 0.45 & 0.11 & 0.27 \\
NIFA15 & 0.90 & 0.07 & 0.19 \\
NIFA30 & 0.68 & 0.13 & 0.21 \\
NISlag30 & 0.97 & & 0.23 \\
\hline
\end{tabular}


From the results of this research, the threshold contents of total chlorides are in the range of $0.45 \sim 0.97$ percent by weight of the cement. These results are similar to those of Hussain et al. (1996), in which for 2.43, 7.59, 14 percent $\mathrm{C}_{3} \mathrm{~A}$ cements, the threshold contents of total chlorides are $0.48 \sim 0.59,0.73 \sim 0.85,1.01 \sim 1.20$ percent by weight of the cement, respectively. Fig. 14 shows the comparison between the results of this research and Hussain et al.'s results ${ }^{14}$ for threshold values of total chlorides. Fig. 15 shows a comparison between present test results and Thomas' results (1996) for the influence of the addition of fly ash. As shown in Fig. 15, the result that threshold values of total chlorides decrease with an increase of the fly ash addition is in reasonably good agreement with the data of Thomas ${ }^{15}$, the difference being the amount of $\mathrm{C}_{3} \mathrm{~A}$ content. This effect results from the decrease of the $\mathrm{pH}$ value by the addition of fly ash.

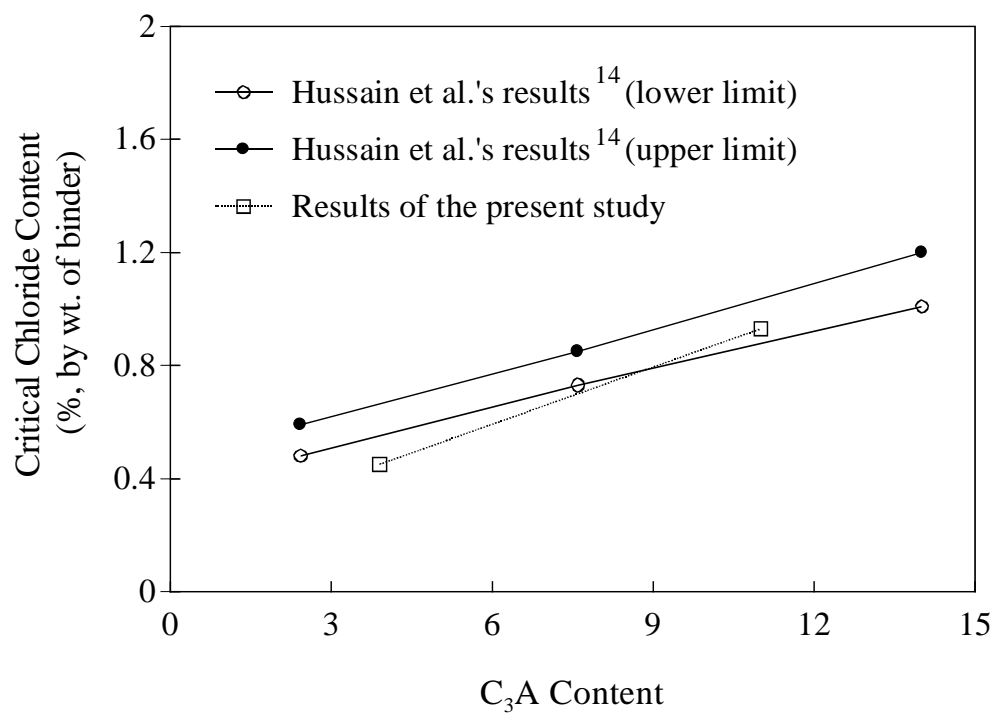

Fig. 14 Threshold total chloride content versus C3A content

As shown in Table 5, the threshold values of free chlorides for all specimens are in the range of about 0.07 0.13 percent by weight of the cement. These values are significantly different from the threshold values of total chlorides, that is, internally a considerable fraction of total chlorides has been bound. Table 5 shows that threshold values of total chlorides are rather different depending upon the type of cement. However, the threshold values of free chlorides for corrosion initiation are approximately constant. This indicates that the free chloride values are more realistic and reasonable to specify the limit values for the corrosion initiation in reinforced concrete structures.

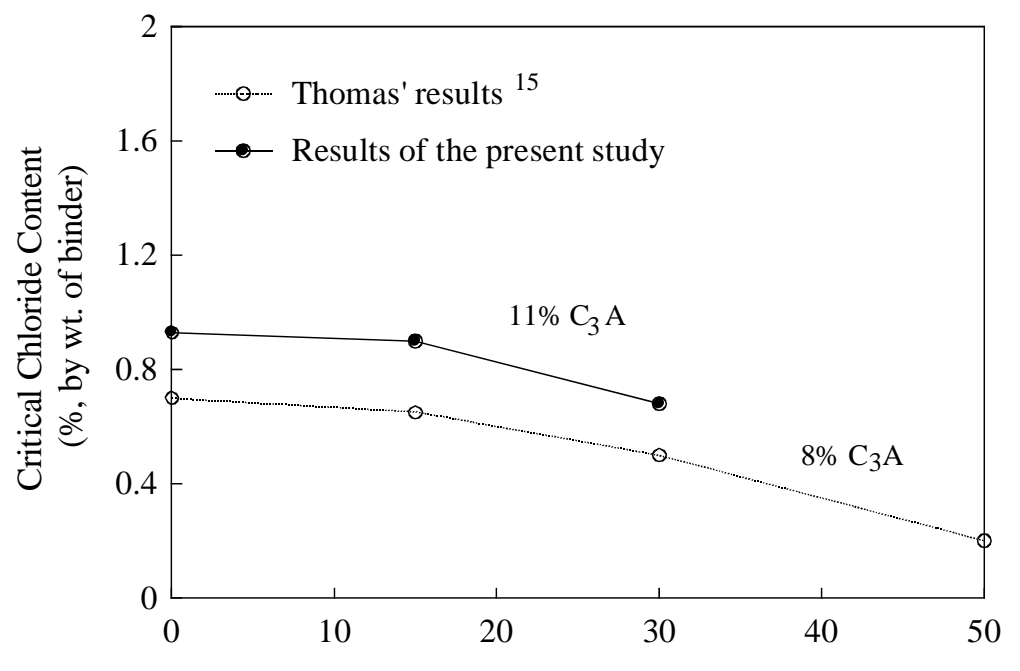

Fly Ash Replacement (\%, by wt. of binder) 


\section{Fig. 15 Threshold total chloride content versus fly ash replacement}

As shown in Table 5, the ratios of threshold values of $\left[\mathrm{Cl}^{-}\right] /\left[\mathrm{OH}^{-}\right]$are in the range of $0.16 \sim 0.26$ depending upon the type of cement or binder. Gouda ${ }^{4}$ proposed the threshold ratio of $\left[\mathrm{Cl}^{-}\right] /\left[\mathrm{OH}^{-}\right]$to be about 0.3 and $\mathrm{Haussmann}^{3}$ gave somewhat larger value of 0.6. However, these threshold values are dependent upon the mixture proportions as well as on the type of binder as shown in this study (see Table 5).

Carbonation may also significantly affect the chloride threshold level. When considering the effect of carbonation on corrosion initiation, the $\left[\mathrm{Cl}^{-}\right] /\left[\mathrm{OH}^{-}\right]$may be more applicable than the free chloride content by weight of binder. However, the effect of carbonation on the threshold value is beyond the scope of this study. According to Gouda ${ }^{4}$, the critical value of $\left[\mathrm{Cl}^{-}\right] /\left[\mathrm{OH}^{-}\right]$increases with decreasing $\left[\mathrm{OH}^{-}\right]$, viz., pH. Fig. 16 shows that the critical values of $\left[\mathrm{Cl}^{-}\right] /\left[\mathrm{OH}^{-}\right]$of this study are in accordance with Gouda's data.

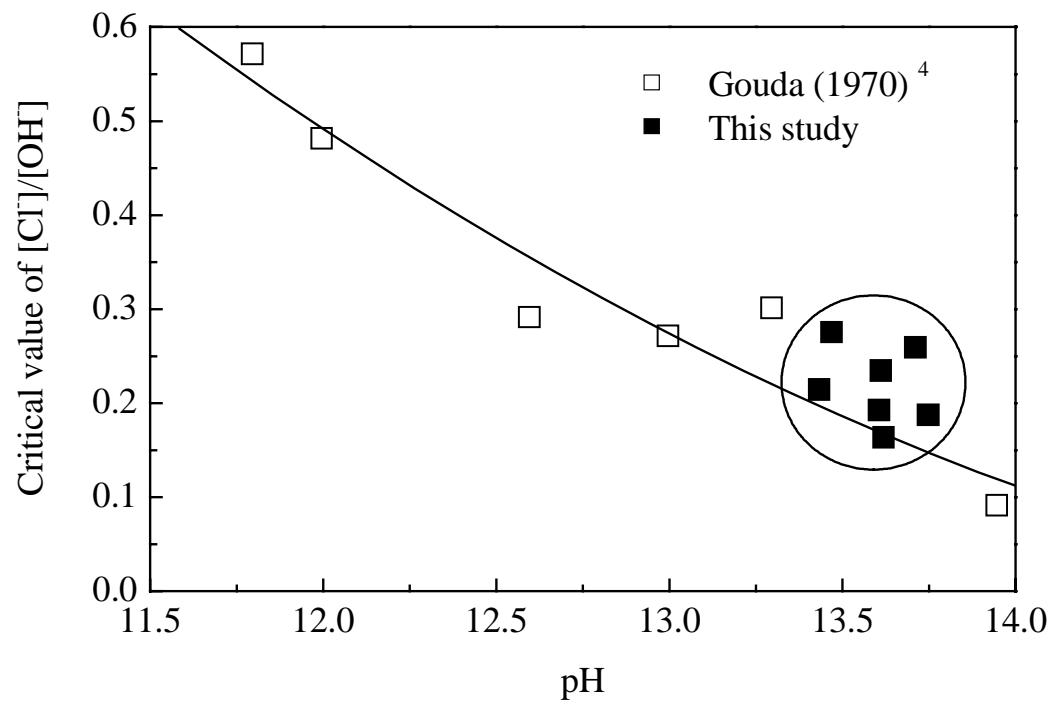

Fig. 16 Critical [Cl-]/[OH-] at different pH's

\section{CONCLUSION}

The corrosion of steel reinforcement is one of the most important aspects in the durability of reinforced concrete structures. The threshold chloride concentration that causes the initiation of corrosion is of particular importance in view of service life prediction. The purpose of the present study is to determine the threshold chloride values that cause active corrosion initiation of steel bars in concrete. To this end, a comprehensive test program has been set up and a large number of test specimens have been tested. The major test variables are the amount of chlorides in concrete, type and amount of cementitious materials and water-to-binder ratios. The chloride concentration of the test specimens varies from zero to two percent by weight of cement. The types of cement considered are type I ordinary portland cement (OPC) and type $\mathrm{V}$ sulfate resisting portland cement (SRPC). The water-to-binder ratios range from 0.55 to 0.35 . The following conclusions have been drawn from the present study.

(1) The half-cell potential values decrease almost linearly with an increase of the content of added chlorides. The concrete mixture with type V cement (sulfate-resisting portland cement) exhibits relatively low values of half-cell potentials at the same total chloride content, compared with other mixtures.

(2) The corrosion area at the same total chloride contents decreases with a decrease of water-to-binder ratio and decreases with the use of mineral admixtures.

(3) The present study indicates that the corrosion of steel initiates at a potential value of about $-0.25 \mathrm{~V}$. The extent of corroded area is about 3 percent for 30 days at the potential value of $-0.35 \mathrm{~V}$.

(4) The free chloride concentration in the pore solution of the hardened mortar increases with an increase of the total chloride addition. It was found that one of the most important factors that affect the chloride binding is the $\mathrm{C}_{3} \mathrm{~A}$ content of the cement. An increase of the $\mathrm{C}_{3} \mathrm{~A}$ content of the cement decreases the free chloride content for a given total chloride content of the concrete. The alkali content and the $\left[\mathrm{OH}^{-}\right]$concentration also affect the chloride binding capacity. The free chloride contents decrease with an increase of these values.

(5) The chloride binding capacity of type V sulfate-resisting cement was found to be lower than that of type I ordinary portland cement.

(6) The threshold total chloride limits for the corrosion initiation range from $0.45 \sim 0.97$ percent by weight of cement depending upon the $\mathrm{C}_{3} \mathrm{~A}$ content. However, the threshold values of free chlorides for corrosion initiation 
have approximately uniform values of about 0.1 percent by weight of the cement. This indicates that the free chloride values are more reliable to specify a limit value for corrosion initiation of reinforced concrete structures. (7) The threshold values of $\left[\mathrm{Cl}^{-}\right] /\left[\mathrm{OH}^{-}\right]$are found to be about $0.16 \sim 0.26$ depending upon the type of cement or binder.

\section{REFERENCES}

Kropp, I., Hilsdorf, H.K. (1995), Performance Criteria for Concrete Durability, Rilem report 12, E \& FN Spon, Rilem, London.

Schiessl, P., (1997), Corrosion of Steel in Concrete, Report of the Technical Committee 60-CSC, Rilem, Chapman and Hall.

Hausmann, D.A., (1967), Steel corrosion in concrete: how does it occur?, Mater. Prot., Vol. 6, No. 11, pp. 19-23. Gouda, V.K., (1970), Corrosion \& corrosion inhibition of reinforcing steel: 1-Immersion in alkaline solution, Brit. Corr. J., Vol. 5, September, pp. 198-203.

Stratfull, R.F., (1973), Half cell Potentials and the corrosion of steel in concrete, presented at the 52nd Annual Meeting of Highway Research Board.

Khan, M.S., (1991), Corrosion state of reinforcing steel in concrete at early ages, ACI Mater. J., Vol. 88, No.1, Jan.-Feb., pp. 37-40.

Lorentz, T., French, C., (1995), Corrosion of reinforcing steel in concrete: effects of materials, mix composition and cracking, ACI Mater. J., Vol. 92, Mar.-Apr., pp. 181-190.

Page, C.L., Lambert, P., Vassie, P.R.W., (1991), Investigations of reinforcement corrosion. 1. The pore electrode phase in chloride- contaminated concrete, Mater. Struct., Vol. 24, pp. 243- 252.

Lambert, P., Page, C.L., (1991), Investigations of reinforcement corrosion. 2. Electrochemical monitoring of steel in chloride-contaminated concrete, Mater. Struct., Vol. 24, pp. 351-358.

Tayyib, Khan, M.S., (1988), Corrosion rate measurements of reinforcing steel in concrete by electrochemical techniques, ACI Mater. J., Vol. 85, May-Jun., pp. 172-177.

ASTM C 876, (1990), Standard test method for half-cell potentials of uncoated reinforcing steel in concrete, Annual Book of ASTM Standards, Vol.03.02.

Barneyback, R.S., Diamond, S., (1981), Expression and analysis of pore fluids from hardened pastes and mortars, Cem. Concr. Res., Vol. 11, No.2, pp. 279-285.

Arya, C., Newman, J. B., (1990), An assessment of four methods of determining the free chloride content of concrete, Mater. Struc., Vol. 23, pp. 319-330.

Hussain, S.E., Al-Gahtani, A.S., Rasheeduzzafar., (1996), Chloride threshold for corrosion of reinforcement in concrete, ACI Mater. J., Nov.-Dec., pp. 534-538.

Thomas, M., (1996), Chloride thresholds in marine concrete, Cement and Concrete Research, Vol. 26, No.4, pp. 513-519.

\section{ACKNOWLEDGEMENTS}

The support from NRL(National Research Laboratory) Program of Korea is greatly appreciated. 